\title{
A América Dividida entre Gabriel Soares de Sousa e Cornelius de Paum
}

\author{
America Divided Between Gabriel Soares de Sousa and \\ CORNELIUS DE PAUW
}

... a casualidade domina o homem e não o homem a casualidade.

(Heródoto, 7.49)

Perché la fortuna è donna, ed è necessario, volendola tenere sotto, batterla ed urtarla.

(Maquiavel, Il Principe)

Luiz Antônio Lindo ${ }^{(*)}$

Resumo: O presente artigo traz uma reflexão sobre a visão antagônica do futuro da América pelos cronistas Gabriel Soares de Sousa e Cornelius de Pauw, considerando-se aspectos como: a influência da natureza sobre o homem, o meio como empecilho ao desenvolvimento máximo esperado do continente latino-americano e quanto à questão do atraso no desenvolvimento da América Latina foi, por séculos, associada a limitações naturais que o clima e a consequente índole humana resultante desse clima trariam. Uma possível solução para elevar a América a um novo patamar moral e superar as vicissitudes do meio, podendo evoluir política e socialmente, seria a existência de um governante que tivesse entranhados o espírito selvagem e o elevado caráter humano, como deveria ser o Príncipe, de Maquiavel.

Palavras-chave: Cornelius de Pauw. Gabriel Soares de Sousa. América Latina. Evolução, natureza e virtude.

\begin{abstract}
This article brings a reflection on the antagonistic vision of America's future by chroniclers Gabriel Soares de Sousa and Cornelius de Pauw, considering aspects such as: the influence of nature on humans, the environment as hindrance to the expected maximum development of the Latin American continent, and the issue of the delay in the development of Latin America was, for centuries, associated with natural limitations that the climate and the consequent human nature resulting from this climate would bring. A possible solution to elevate America to a new level and overcome the vicissitudes of the medium, which may evolve politically and socially, it would be the existence of a ruler who had entrenched the wild spirit and high human character, as it should be the Prince of Machiavelli.
\end{abstract}

Key-words: Cornelius de Pauw. Gabriel Soares de Sousa. Latin America. Development, nature and virtue.

(*) Professor da Faculdade de Filosofia, Letras e Ciências Humanas (FFLCH) e do Programa de Integração da América Latina (PROLAM) da Universidade de São Paulo (USP). E-mail: <lal@usp.br>. Recebido em 1ํ․07.2012 e aceito em 17.10.2012. 
Sabemos de lugares em nosso planeta que são particularmente inóspitos à vida humana. Poucos ousariam conceber uma morada de homens nas profundezas abissais, nos desertos inclementes, junto aos picos dos montes mais sobranceiros ou nas geleiras perenes de nossa Terra. A simples ida a tais lugares em geral representa antes um desafio, um anseio de conquista visando a registrar um feito, uma aventura ao alcance apenas de indivíduos ou grupos isolados, que nada têm de similar à segurança da vida normal que o homem deseja gozar no seu quotidiano. Se olharmos para trás no tempo veremos que para o comum dos homens ocidentais a América e nela o Brasil já chegaram a representar um desafio semelhante ao que costumam enfrentar em suas façanhas implausíveis os homens destemidos e dados à aventura. É que houve um período, imediatamente após a descoberta e os primeiros contatos com os habitantes nativos, em que se podia duvidar ser o novo continente como um todo, um espaço apto a receber a vida humana na sua forma civilizada. Sem nada ou quase nada saber das condições vigentes no espaço físico que no princípio era misteriosamente chamado de Mundo Novo, vinham a propósito as informações que permitissem tomar pé da situação real. Por isso, os primeiros navegadores e expedicionários olhavam com atenção máxima o que se lhes deparava o meio e desejavam muito saber se os nativos porventura encontrados estavam predispostos ao convívio social. Exímios observadores, eles procuravam avaliar se o que estava à mostra era tudo que havia digno de ser notado ou se estaria o acaso reservando obstáculos inauditos.

Foi nos primeiros relatos escritos sobre a América e o Brasil, as chamadas crônicas dos tempos que se seguiram à descoberta, que as observações passaram à forma de texto documentário. Os cronistas foram os primeiros a elaborar o inventário da realidade física e humana das diferentes províncias da América. No caso brasileiro em particular, merece menção o Tratado Descritivo do Brasil, de Gabriel Soares de Sousa, especialmente ilustrativo a esse respeito, pela minuciosa sondagem que faz da flora e da fauna, bem como dos costumes das nações indígenas encontradas ${ }^{(1)}$. As informações fornecidas pelos cronistas em geral dão conta duma natureza pródiga e de nações aborígenes vivendo como se supõe que vivam os homens reunidos para a vida em comum. Nesta emblemática passagem, Gabriel Soares de Sousa, ele mesmo a um tempo observador e empreendedor, resume a que conclusão chegara com as suas investigações e a que tarefa podiam propor-se os homens envolvidos na construção do novo cosmion brasileiro, considerando a realidade existente: "Em reparo e acrescentamento estará bem empregado todo o cuidado que Sua Majestade mandar ter deste novo reino, pois está capaz para se edificar nele um grande império, o qual com pouca despesa destes reinos se fará tão soberano que seja um dos Estados do mundo." (op. cit., Proêmio, p. 40.) Sua previsão devemos aceitá-la hoje com

(1) O cronista visava prover as autoridades, em primeiro lugar o rei, das informações que faziam falta na tomada de decisões. Esta preocupação consta já do proêmio da primeira parte do Tratado, denominada Roteiro Geral da Costa Brasílica, onde se lê: "Como todas as coisas têm fim, convém que tenham princípio, e como o de minha pretensão é manifestar a grandeza, fertilidade e outras grandes partes que tem a Bahia de Todos os Santos e demais Estados do Brasil, do que os reis passados tanto se descuidaram, a el-rei nosso senhor convém, a ao bem do seu serviço, que lhe mostre, por estas lembranças, os grandes merecimentos deste seu Estado, as qualidades e estranhezas dele, etc., para que lhe ponha os olhos e bafeje com seu poder, o qual se engrandeça e estenda a felicidade..." (Tratado Descritivo do Brasil em 1587. São Paulo: Companhia Editora Nacional/Editora da Universidade São Paulo, 1971. p. 39. 
responsabilidade, pelo fato de habitarmos as mesmas terras que ele pisou, sentindo-nos razoavelmente confortáveis para confirmar o seu testemunho favorável quanto à possibilidade de nelas viver com dignidade.

Para os primeiros habitantes do Mundo Novo, viver adequadamente significava estabelecer a melhor ordem política possível. Na Política, Aristóteles nos faz compreender esse ponto, quando diz que a primeira coisa a considerar no estabelecimento do regime político são "as condições da polis ideal ou perfeita; pois a polis perfeita não pode existir sem as reservas adequadas dos meios de vida. E por isso devemos pressupor várias condições puramente imaginárias, mas nada que seja impossível (adynatos). É preciso existir um certo número de cidadãos, um território no qual abrigá-los, e daí por diante. Assim como o tecelão ou construtor naval ou qualquer outro artesão deve dispor do material adequado para realizar seu trabalho (e na medida em que tenha recebido o melhor preparo, a fim de que sua obra resulte mais perfeita), assim o estadista ou legislador deve também dispor do material que mais lhe convém". (Política, 1325b 35-1326a 4) O primeiro item a considerar será pois a população (1326a 5), quanto ao número (plethos) e ao caráter (physis); definido o número adequado, o qual não pode ser demasiado grande nem pequeno, uma proporção será constituída pelos cidadãos efetivos, "a parte essencial" da polis: "O número destes constitui uma prova da grandeza duma cidade." (1326a 23) A polis "só começará a existir quando tiver atingido uma população em número suficiente para uma vida boa na comunidade política". (1326b 8) Quanto ao caráter dos cidadãos, vale o que é efetivamente observado em cada parte do globo, ou seja, o que revela a experiência dos diferentes povos do "mundo habitável". Aristóteles julga influir no caráter o clima, cuja variedade iria de par com as disposições psíquicas. O termo médio climático constitui o ideal, coincidente aliás com o termo médio político, cujo exemplo mais notável citado por ele procederia dos povos helênicos. O critério principal para se ter o melhor caráter é a presença da liberdade na organização política, a qual se tem e se mantém graças às qualidades de inteligência e brio (próprias do homem enthymon kai dianoetikon) (1327b 20-31) $)^{(2)}$ O legislador colheria nos, simultaneamente, inteligentes e corajosos os melhores frutos da virtude (arete) $)^{(3)}$, fator imprescindível na construção da boa cidade (1327b 37). Se a obra em vista, como pensava Aristóteles, consiste na edificação da vida boa, é preciso contar com os meios adequados para tanto, os materiais e os humanos, os quais são essencialmente naturais e providos, portanto, pelo acaso. É deste modo que as determinações naturais obrigam o legislador e o povo a agirem no plano estrito do possível.

Passados aproximadamente duzentos anos dos primeiros escritos cronísticos, Cornelius de Pauw (1739-1799), um etnólogo holandês de nomeada ${ }^{(4)}$, no livro Recherches

(2) Enthymos, de en e thymos. Em 1327b 40-41 lê-se: "O thymos é a qualidade da alma que gera amizade e nos possibilita amar." E ainda em 1328a 6-8: "O poder de mando e o amor da liberdade residem em todos os homens nesta qualidade, pois o thymos é preponderante e invencível.” A dianoesis é o exercício da inteligência mediante o logos discursivo.

(3) O significado de arete é "excelência".

(4) Em vida, ele foi considerado a maior autoridade em América, embora não tivesse posto os pés no continente. Isto não o impediu de ser convidado para escrever artigos para a Encyclopédie e de ser homenageado por Napoleão com um obelisco. Era amigo dos intelectuais iluministas, com os quais se correspondia, incluindo Voltaire. Suas ideias, retratadas com tintas fortes, fazem companhia às de Buffon (Georges-Louis Leclerc, conde de) e às do abade Raynal 
philosophiques sur les Américains, ou Mémoires intéressants pour servir à l'Histoire de l'Espèce Humaine. Avec une Dissertation sur l'Amérique E les Américains, procurou demonstrar que a América sob todos os aspectos era inferior à Europa. Baseando-se aparentemente em informações esparsas de "espanhóis", ele descreve o indígena americano como uma "raça de homens, de que a indolência era a principal característica"; "depois de comer e dançar a maior parte do dia, eles gastavam o resto do tempo dormindo, sem pensar no amanhã. A maioria não tinha capacidade de refletir nem memória, andavam seminus e geralmente estavam inebriados pelo fumo"(5). "Os homens, prossegue, não tinham barba, ou pelos no corpo, como os eunucos; eram quase insensíveis à paixão do amor; tinham leite, ou uma espécie de líquido leitoso, nos mamilos; não podiam ou não queriam carregar pesos, e os homens e mulheres estavam contaminados pela doença venérea; tal era a preguiça dos homens e sua aversão pelo trabalho, que nem mesmo a necessidade extrema, a que frequentemente se viam sujeitos, os dispunha a cultivar a terra; confiando para tudo na natureza, e permaneciam estranhos absolutos à indústria." (ib., p. 2) O caráter, que Aristóteles apontava como a condição indispensável para a boa organização da sociedade, constitui justamente o traço mais desabonador desse nativo: "O americano, falando com precisão, não é virtuoso nem vicioso. Que motivo teria ele para ser uma coisa ou outra? A timidez de sua alma, a fraqueza de seu intelecto, a necessidade de prover a sua subsistência, a força da superstição, a influência do clima, tudo o leva para muito longe da possibilidade de se aperfeiçoar; mas ele não o percebe; sua felicidade é não pensar; permanecer na completa inação; dormir um bocado; nada desejar, uma vez saciada a fome; e não se preocupar com nada a não ser com os meios de procurar comida quando atormentado pela fome. Não se prestaria a construir uma cabana, se o frio e o tempo inclemente não o forçassem a tal, nem sequer deixaria a cabana, se não fosse obrigado a tanto. Em seu entendimento não há gradação, continua sendo uma criança até o último instante de sua vida. Por sua natureza indolente ao extremo, mostra-se vingativo por fraqueza, e atroz em sua vingança, porque é ele mesmo insensível; nada tendo a perder senão a vida, vê todos os inimigos como um bando de assassinos. Se seus planos de vingança dependessem de coragem para lograr a sua execução, não haveria na terra um animal mais terrível; nem seria ele menos perigoso aos próprios europeus, do que é para as pequenas hordas com que se mete em guerra, e que, não sendo mais corajosas do que ele, tornam a partida igual, e suas guerras eternas." (ib., p. 16) O destino dos europeus emigrados, por sua vez, é tornarem-se eles próprios "degenerados, como os animais; uma prova de que o clima é desfavorável ao aperfeiçoamento tanto do homem quanto do animal. Os criollos, descendentes de europeus e nascidos na América, embora educados nas universidades do México, de Lima e no Colégio de Santa Fé, nunca produziram um único livro. Esta degradação da humanidade deve ser atribuída às qualidades viciadas do ar estagnado em suas imensas florestas e corrompido pelos vapores nocivos das águas paradas e dos campos sem cultivo." (ib., p. 17-18) "Os criollos, continua, tanto

(Guilherme Thomas François). Conquanto seguisse as linhas gerais da tese da degenerescência americana, de Buffon, Pauw emprestou a ela o seu prestígio e a sublinhou com a tese suplementar do abastardamento físico e moral do europeu transplantado na América. Entre os seus adversários, contaram-se os cronistas Clavigero, Molina e Gilij, além dos críticos Pernety e Bonneville, que procuraram apontar as suas inexatidões.

(5) As citações foram extraídas de Selections from M. Pauw, with Additions by Daniel Webb. Londres, 1795. p. 1-2. 
da América do Sul quanto do Norte, amadurecem sua inteligência, tal como as têm, mais cedo do que as crianças europeias; mas esta antecipação da maturidade tem vida breve, em proporção à intempestividade de sua aparência; pois o criollo decai, ao se aproximar da puberdade; sua vivacidade o abandona, suas forças se apagam e ele deixa de pensar exatamente quando poderia pensar com algum propósito: por isso se diz que já estão cegos no momento em que os outros homens começam a ver." (ib., p. 18)

Pauw insiste em atribuir a deficiência do homem americano às condições climáticas do meio em que é obrigado a viver. O ar malsão seria o responsável pela propagação de "insetos, serpentes venenosas, vegetação contaminada" que "distinguem tão infortunadamente este hemisfério. As mesmas qualidades ruins do ar que são favoráveis aos produtos tóxicos são provavelmente a origem real da degenerescência dos homens e animais; assim como os líquidos contaminados que infectam a natureza vegetal devem macular o sangue e subjugar as forças do animal" (ib., p. 35). Em consequência do clima inóspito da América, teriam malogrado ou sido prejudicados o cultivo do arroz, da uva e do vinho, do café, da cana-de-açúcar. Os animais também deixariam a desejar:

"Observou-se, diz, por ocasião da descoberta do Mundo Novo, que nenhum quadrúpede de grande porte foi encontrado nos Trópicos; não havia cavalos, asnos, bois, camelos, dromedários ou elefantes; todos os quais, exceto os últimos, foram desde tempos imemoriais domados para servir ao homem em nosso hemisfério...

"O puma, ou leão da América, não tem juba; nem pode ser comparado pelo tamanho, força ou coragem ao leão da África. O mesmo se pode dizer do jaguar, que foi honrado com o nome de tigre; assim também o cougar, ou tigre covarde, como é chamado, que parece peculiar a este país." (ib., p. 31-32) "Em geral, a América não poderia jamais ser povoada como a Europa e a Ásia", por estar "coberta de pântanos imensos, que tornam o ar sumamente malsão, e o solo produtivo dum número prodigioso de vegetais venenosos. Pode-se viajar por vastas solidões da América do Norte sem encontrar uma única habitação ou traço do homem." (ib., 21) A influência nefasta do clima sobre os homens, a flora e a fauna é tal que os naturalistas são unânimes em afirmar que "os animais trazidos da Europa para a América degeneram; a mesma deterioração que predomina nos animais mais robustos se estende aos homens, que, em diferentes regiões, têm sofrido disenterias epidêmicas mais ou menos letais. A grande umidade da atmosfera, a quantidade prodigiosa de águas estagnadas, os vapores tóxicos, os líquidos deteriorados e as qualidades prejudiciais das plantas e alimentos, contam para a fraqueza da compleição, a aversão pelo trabalho e a inadaptação geral para todo tipo de melhoria, o que tem impedido os americanos de emergirem da vida selvagem". (ib., p. 27-28) A ausência de realizações do homem americano, bem como a inépcia das do resto do mundo, quando confrontadas com a exuberância da criação européia, não deixariam margem a dúvidas quanto à distância que há de separar os continentes da terra: "Por toda a extensão da América... nunca apareceu um filósofo, um artista, um homem erudito ou destacado, cujo nome tenha encontrado um lugar na história das ciências ou cujo talento lhe tenha granjeado nomeada ou sido útil aos demais.

"A Europa é o único lugar no mundo em que se encontram filósofos e astrônomos, pois os chineses, com todas as suas jactâncias, não têm nenhum. Também não têm escultores, pintores ou arquitetos, assim como os outros povos da Ásia; seus poetas são meros trovadores; quanto ao drama é grande a diferença entre a Taha-o-chi-cou-Ell, sua melhor tragédia, e a Phèdre de Racine..." (ib., p. 28-29) 
Apesar da grande diversidade de povos que compõem a Europa, Pauw decide abarcá-la sob uma mesma noção. A categoria antropológica "Europa" surge assim aos seus olhos como uma generalidade até certo ponto homogênea, a qual passa a empregar no confronto com a congênere "América" ${ }^{(6)}$. Enquanto aquela corresponderia à parte nobre do mundo natural e histórico, a outra corresponderia à parte vil. Operando sob a rubrica "história natural", Pauw, a exemplo de outros cientistas de seu tempo, entendia que os dados obtidos mediante observação da natureza deveriam conduzir a conclusões acertadas, quando em aliança com o outro braço do seu método científico, qual seja, a "história", encarregada de avalizar os "produtos" naturais observados. A empiria industriosa unia-se assim à sabedoria ínsita na natureza, traduzindo-se em juízo histórico isento de subjetividade, a ser enunciado pelos exemplares humanos intelectualmente mais perfeitos na linha de produção filogenética. A "história", idêntica à evolução ou progresso, desde que contada pela própria physis, vinha pois fornecer lições morais como uma magistra vitae naturalis.

À parte outras considerações, pode-se dizer que o componente moral inerente à sentença pauwiana, qual seja, a primazia conferida aos europeus sobre os outros povos, reflete um senso extremado de magnanimidade (megalopsychia) ${ }^{(7)}$. Possuído de grandeur, o sentencioso não pode descer completamente a escada da humildade, mas, se tiver que descer, haverá de parar em algum degrau onde possa conservar um quantum de dignidade, e daí não passará. Em verdade, o grand homme não cogita descer, porém, subir, subir sempre. Passados pouco mais de dois séculos, continua lícito contudo, perguntar como foi possível a um especialista como Pauw ir tão longe na defesa duma ideia ${ }^{(8)}$ tendente a negar a unidade do gênero humano.

Digno de notar, por fim, é como a depreciação por Pauw da natureza e do homem americanos está em pleno contraste com o diagnóstico favorável feito pelos cronistas. Nesse sentido, pode-se dizer que a sua tese resiste ou desaba na medida em que desaba

(6) Foi em parte o tratamento generalizador de Buffon e seguidores, inculcado no desprezo pela América, que levou T. Jefferson a defendê-la, elegendo como contraprova dos argumentos desacreditadores o porte majestoso do alce. Sobre o episódio, vide, de L. A. Dugatkin, Mr. Jefferson and the Giant Moose Natural History in Early America. The University of Chicago Press, 2009.

(7) Como o definiu R. A. Gauthier, in Magnanimité l'Idéal de la Grandeur dans la Philosophie Païenne et dans la Théologie Chrétienne, J. Vrin, 1951, "ser magnânimo é pois, num sentido primeiro, não poder suportar uma afronta" (p. 21). A noção de magnanimidade permeou todo o paganismo. Aristóteles, nos Analíticos Segundos (B, 13, 97b 15-25) distingue dois sentidos, um deles o de não suportar uma afronta, o outro, o da impassibilidade perante as vicissitudes da sorte. O primeiro sentido deu origem à magnanimidade dos políticos, o segundo, à dos filósofos. A manifestada por Pauw se enquadraria em sua justa medida na categoria política.

(8) Em verdade, Pauw foi contestado imediatamente, valendo lembrar a crítica de Pernety, Examen des recherches philosophiques sur l'Amérique et les Américains, 1771, à qual respondeu in Defense des recherches philosophiques sur les Américains, Berlim, 1772, e a de Bonneville, De l’Amérique et des Américains, 1771. Na Defense, ele afirma ter pretendido "demonstrar a vantagem infinita que tem a vida social sobre a vida selvagem, a vantagem infinita que têm os habitantes da Europa sobre os indígenas do novo Mundo. As nações que produziram homens tão grandes como Newton, Locke, Leibnitz, Descartes, Bayle, Montesquieu, s'Gravesand não são somente superiores, mas infinitamente superiores aos bárbaros da América, que não sabem nem ler, nem escrever, nem contar além de seus dedos" (p. 6-7). Depois de dizer, no preâmbulo das Recherches philosophiques sur les Américains, ou Mémoires intéressants pour servir à l'histoire de l'espèce humaine (1772), que "não há acontecimento mais memorável para os homens do que a descoberta da América", ele lamenta "o espetáculo grande e terrível de ver metade do globo tão infelicitado pela natureza, a ponto de tudo ali ser degenerado ou monstruoso" (p. III-IV). 
ou resiste aquele diagnóstico. O seu ponto de vista tem, portanto, um componente revisionista, com o qual parece procurar atingir o estado de coisas tal como era concebido anteriormente. Ao caminhar nessa direção, menospreza as consequências que a sua visão acarreta, a maior delas a de que a América seria, material e intelectualmente falando, uma terra inviável, imprópria para abrigar a civilização, pois ainda que não inteiramente inóspita à vida social, ela estaria impedida de alcançar o desenvolvimento máximo que se espera haver nas grandes nações do mundo, particularmente o estabelecimento da vida boa de que fala Aristóteles. Tendo vindo à luz, passados pouco mais de duzentos anos desde o descobrimento, o que a situa a meio caminho em relação ao nosso próprio tempo, essa visão representa um desafio ao menos para quem se atém à propalada questão do atraso da América latina. Quando ela foi divulgada, parte considerável do processo colonizador estava já cumprida. E foi por ser aceita e talvez até esperada ${ }^{(9)}$ que gozou do mesmo prestígio científico conferido à etnologia, uma ciência recente ${ }^{(10)}$ que a fama de Pauw, respeitado em seu tempo como um grande conhecedor das coisas americanas $^{(11)}$, ajudou a consolidar. Seguir o método prescrito para trabalhos no gênero, como ele fez enquanto etnólogo ${ }^{(12)}$, devia granjear mais crédito do que o conferido aos cronistas, cujos escritos, despojados de terminologia e repletos de indigenismos, oscilavam entre o relatório e a narrativa literária. As conclusões metódicas de Pauw eram tidas por inferências obtidas a partir da análise do material sobre o qual agiam as forças naturais. Surgiam como a elucidação dos fatores que contavam na produção natural dos fenômenos. Por isso, não era sua intenção, mas uma obrigação, prever o fracasso duma civilização porventura erguida em bases exemplarmente precárias, a despeito da lástima que provocaria em quem estivesse procurando superar as adversidades. De todo modo, prestava um serviço à sociedade como membro da classe de cientistas esclarecidos de seu tempo, cujo saber notável tinha por propósito ilustrar a humanidade, salvando-a da obscuridade.

De outro lado, admitida, à guisa de exercício didático, a hipótese da degeneração, e ainda assim insistindo, em nome do desejo de todos em todos os tempos, em instituir uma vida digna e proveitosa na América sujeita ao destino traçado por Pauw, que decisões deveriam ser tomadas para se conseguir o melhor diante das condições oferecidas? Em primeiro lugar, está claro que as decisões não poderiam refletir a consciência dos indivíduos situados abaixo da linha que faculta as boas escolhas. Em segundo lugar, não há dúvida de que os obstáculos naturais representados pelo meio teriam de ser vencidos não com um saber qualquer, mas com um capaz de elevar ao máximo as possibilidades humanas; esse saber obviamente provém da experiência e da ciência. Considerando que os agentes empenhados nessa magna tarefa seriam, duma parte, indivíduos de moral ímpar e, de outra

(9) Muitos intelectuais fizeram vista grossa ao fato de as informações por ele usadas provirem de terceiros. E acrescente-se a isso a boa reputação que veio a desfrutar em razão de seus escritos (vide nota 4 , acima).

(10) A etnologia, como ramo da antropologia, ganhou grande impulso com a descoberta da América, tendo-se tornado disciplina acadêmica no século XVIII. Uma de suas metas é a reconstrução da história do mundo, objetivo reconhecido como válido em nossos dias, o que Pauw procurou cumprir sem titubear.

(11) Vide nota 4, acima.

(12) Supõe-se que de algum modo deveria ser considerado mais verídico o que pesava contra do que o que pesava a favor, quando se tratava de dar um testemunho fiel da realidade americana. Há várias passagens nas crônicas que podem contribuir para coonestar essa inclinação de ânimo. 
parte, os mais competentes na prática e na teoria, conclui-se que encontrá-los entre a "raça degenerada" americana tal como descrita por Pauw seria altamente improvável. Seria plausível então imaginar que homens importados do continente europeu, onde os estudos de Pauw mostraram residir os melhores, estivessem mais capacitados a enfrentar esta imensa tarefa, conquanto mesmo eles, por mais energia e talento que possuíssem, estariam sujeitos a um redondo fracasso, como aqueles mesmos estudos apontaram em relação aos criollos. Em verdade, para se ter uma ideia do que seria necessário possuir para levar a cabo tal empresa, faz falta toda a força da imaginação. Só por invocação às musas, em paralelo com a evocação em sentido inverso dos trechos mais alusivos das obras do chamado realismo mágico, pode-se afinal vislumbrar alguma coisa de formidável impregnando a personalidade dos homens que se aboletassem a conduzir o comboio da América precária pelas veredas do menos provável ou do quase impossível. O poder dessa classe de titãs teria de se mostrar afim ao absoluto divino, quando comparado à potência ordinária dos seres normais, aptos tão-só a seguir o curso de sua vida naturalmente ordenada. Aquele poder seria pois tanto mais extraordinário quanto mais se fizesse capaz de reordenar os elementos naturais e morais de seus súditos degenerados. O problema é que, estando esses indivíduos demasiado acima do comum, fica difícil saber se os critérios para as melhores escolhas que fariam seriam aqueles que podemos julgar como as melhores pelo senso comum ou pela tradição, os únicos meios de que dispomos para tanto. Nesse ponto, surge, portanto, a questão de saber que escolhas seriam feitas. Sabe-se que quem pode o mais pode o menos, assim como quem tem menos quer mais, mas como ter certeza de que a vontade de quem ordena e a de quem se sujeita às ordens podem encontrar-se num ponto comum que propicie o arranjo perfeito de espaço e tempo no qual o superior e o inferior, afinal unidos, passam a escalar juntos a subida para o desenvolvimento supremo? Projetando esse movimento de transição para a América, cada elemento que a compõe precisaria sair da condição sob a qual foi apreciada por Pauw e mover-se como um só bloco, sem o que ela continuaria presa da imperfeição, sujeita à inércia que a retarda. Se um único "parafuso" dessa máquina viva se soltasse no percurso, todo o esforço despendido para fazê-la operar na marcha para o alto teria sido inútil, pois teríamos um todo desmembrado em partes coordenadas e em partes descordenadas impedindo o avanço.

Desse modo, a intervenção visando a uma reforma moral da sociedade americana, desde que encarada como desafio, à vista do modelo de crítica pauwiana, acabaria tendo de enfrentar a questão da dissensão profunda entre o desejo do agente político encarregado de fazê-la (seja ele um indivíduo, um povo estrangeiro ou um partido político com qualidades extraordinárias) e a capacidade e o interesse da maioria em efetuar a mudança. A intervenção nesses moldes representaria um risco para a normalidade da sociedade estabelecida. Não só o desejo implícito na escolha do modelo político pelo potentado traria em si um grande perigo, mas também a ciência que teria de ser empregada para levar a bom termo a transição para um patamar moral elevado, pois o saber nesse caso estaria a serviço da vontade de efetuar tal transição e simultaneamente desobrigado de seguir o conselho de senso comum da maioria. Nesse sentido, as manobras para enfrentar o desafio da crítica pauwiana e criar uma sociedade exemplar a partir de recursos exíguos implicam em última análise uma revolução no sentido mais pleno do termo. Vale dizer, uma revolução que no seu ponto mais crítico tem de resolver o problema da transformação da natureza humana. 
Interessante é notar que o diagnóstico de Pauw não gira no vazio na história do pensamento. O autor é condizente com uma certa visão de homem que já não vive integralmente "na" natureza, mas habita um mundo próprio, um mundo perceptivelmente humano, porém, sujeito a uma remodelagem exaustiva, pronto a ser criado e recriado vezes sem conta sob a batuta de personalidades extraídas à espécie como se se tratasse de criaturas existindo numa realidade distinta. Contrariamente ao homem que é e se representa fundamentalmente um só, em que pese a diversidade de sua conformação, condicionada pelas formas de existir fundadas na variação do ritmo cósmico, este "outro" homem estaria apto a imaginar e criar um mundo especial à sua semelhança, o "seu" mundo, no qual ele se esmera em driblar as vicissitudes do acaso e em violar as leis naturais. O teórico mais notável dessa maneira de ver, por sua capacidade de apresentar um projeto de vida ao homem moderno, em que a existência se apresenta em pragmática desarmonia, foi Maquiavel. No Príncipe ${ }^{(13)}$, descrevendo-se um Quíron ${ }^{(14)}$ preceptor de príncipes, "mezzo bestia e mezzo uomo" (cap. XVIII), ele conclama o governante a usar ambas as naturezas, pois "uma sem a outra não dura". O príncipe precisa saber usar o "bicho" que há dentro de si, um híbrido entre "a raposa e o leão": o leão, porque "não se defende dos laços", e a raposa, porque "não se defende dos lobos" necessitam complementar-se mutuamente. "É preciso pois ser raposa para conhecer os laços, e leão, para afugentar os lobos." (ib.) A assunção da natureza animal torna-se uma medida de justiça, porque os homens não são todos bons: "Se os homens fossem todos bons, este preceito não seria bom; mas como são odiosos, e não o observariam com você, você também não tem que observar com eles." O príncipe deve saber "disfarçar" a natureza da raposa e "ser grande simulador e dissimulador; e são tão simples os homens, e obedecem tão bem às necessidades presentes, que aquele que engana encontrará sempre quem se deixe enganar" (ib.). Restam poucas dúvidas de que se um tal governante (um indivíduo, o estrangeiro ou um partido extraordinários) tomasse o poder na América, com o fim de elevá-la a um novo patamar moral, tudo faria no sentido de sublevar o espírito do "selvagem" pauwiano entranhado no "seu" povo e forçá-lo a fazer-se como ele, forte e orgulhoso. Com a visão dos fins ditados por seu desejo e os meios de realizá-los com a energia e a liberdade necessárias para superar os obstáculos naturais, trataria de juntar o impossível ao possível com a naturalidade de quem calça os próprios sapatos. Com toda certeza, caso fosse bem-sucedido, deixaria aos súditos como legado um bem que se tem por grande patrimônio na contabilidade das operações políticas modernas: o sentimento de magnanimidade.

\section{REFERÊNCIAS BibLIOGRÁFICAS}

ARISTÓTELES. A Política. Tradução Nestor Silveira Chaves. Bauru, SP: Edipro, 1995.

BONNEVILLE, Zacharie de Pazzi. De l'Amérique et des américains, ou Observations curieuses du philosophe La Douceur, qui a parcouru cet hémisphere pendant la dernière guerre, en faisant le noble métier de tuer des hommes sans les manger l'Amérique et des Américains. Berlim: Chez Samuel Pitra, 1771.

(13) In: Opere Complete di Niccolò Machiavelli, vol. I, Ernesto Oliva, Milão, 1850.

(14) Centauro da mitologia, superior aos outros centauros, por seus dotes de inteligência e bondade. De qualquer modo, era filho dum titã. 
DUGATKIN, Lee Alan. Mr. Jefferson and the Giant Moose Natural History in Early Americ. Chicago: The University of Chicago Press, 2009.

GAUTHIER, R. A. Magnanimité. l'idéal de la grandeur dans la philosophie païenne et dans la théologie chrétienne. Bibliothèque thomiste, XXVIII, Paris: Vrin, 1951.

OPERE Complete di Niccolò Machiavelli, vol. I, Ernesto Oliva, Milão, 1850.

PAUW, Cornelius. Defense des recherches philosophiques sur les Américains. Berlim: Chez G. J. Decker, 1772.

PAUW, Cornelius; PERNETY, Antoine-Joseph. Recherches philosophiques sur les Américains, ou Mémoires intéressants pour servir à l'Histoire de l'Espèce Humaine. Avec une Dissertation sur l'Amérique Eles Américains. Imprint Collection. London: Library of Congress, Pre-1801.

PAUW, M. Selections from M. Pauw, with Additions by Daniel Webb. Esq. Londres: Bath, 1795.

PERNETY, Antoine-Joseph. Examen des Recherches philosophiques sur l'Amérique et les Américains, et de la Défense de cet ouvrage . Berlim: Chez G. J. Decker, 1771.

SOUSA, Gabriel Soares de. Tratado Descritivo do Brasil em 1587. São Paulo: Companhia Editora Nacional/Editora da Universidade de São Paulo, 1971. 


\title{
A Geopolítica na Construção da Visão Brasileira sobre a Bolívia
}

\author{
The Geopolitics in the Construction of the Brazilian vision about Bolivia
}

Diego Pereira de Siqueira $\left.{ }^{*}\right)$

Resumo: Este artigo tem por objetivo analisar a maneira como foi construído, entre setores intelectuais ligados às forças armadas e ao aparelho de Estado brasileiro, uma determinada ideologia a respeito do papel da Bolívia para a hegemonia do Brasil dentro do subsistema regional sul-americano. Sustenta que essa ideologia tem por seus fundamentos conceitos geopolíticos elaborados pela primeira vez durante a disputa das principais potências europeias por novos mercados, e, aplicados ao caso sul-americano, orientaram a política externa brasileira com o objetivo de impor uma "satelitização" da Bolívia e a captura de seus recursos naturais, em especial o gás. Chegamos assim à conclusão de que os esquemas de integração regional liderados pelo Brasil, surgidos a partir da década de 1990, podem ser vistos como uma atualização dessas teses geopolíticas.

Palavras-chave: Geopolítico, legemonia brasileira, gáz boliviano.

\begin{abstract}
This article aims to analyse the way a particular ideology was constructed, between intellectual sectors linked to the armed forces and the Brazilian state apparatus, about the role of Bolivia for the hegemony of Brazil within the South American regional subsystem. It argues that this ideology has as its foundations geopolitical concepts developed for the first time during the dispute of the major European powers for new markets, and, when applied to South American scenario, guide Brazilian foreign policy aiming to impose a "satellitisation" of Bolivia to capture its natural resources, especially gas. Thus we come to the conclusion that regional integration schemes led by Brazil, emerged during the 1990s, can be seen as an update of these geopolitical theses.
\end{abstract}

Key Words: Geopolitics, Brasilian legemony, Bolivian gaz.

(*) Mestre pelo Programa de Integração da América Latina (PROLAM) da USP. E-mail: <diegoig.cpm@ig.com.br>. Recebido em 24.08.2012 e aceito em 11.10.2012. 


\section{GeOPOLÍTICA: CONCEITOS E PRECURSORES}

Pode-se encontrar a origem da geopolítica enquanto um sistema definido de proposições no pensamento de Friedrich Ratzel (1844-1904), professor de geografia nas cidades de Munique e Leipzig e autor da obra Antropogeografia. Pretendendo aplicar a Geografia à História, seu pensamento está marcado por um intenso organicismo e determinismo, duas tendências muito em voga na época: Ratzel acreditava que o Estado seria um ser vivo, orgânico, que crescia como todo ser vivo e que, crescendo, sentia necessidade de expansão. Afirmava ainda que, sendo uma entidade orgânica, era da natureza do Estado "romper as barreiras inorgânicas dos limites políticos, se assim o exigia a sua atividade vital" (CHIAVENATO, 1981, p. 13).

No entanto, o termo "Geopolítica” surge apenas com Rudolf Kjellen (1864-1922), no livro O Estado como uma forma de vida, em 1916. Kjellen, professor da Universidade de Gotemburgo, segue a visão organicista de Ratzel, com a diferença que dá um rigor conceitual maior à ciência que batizou: "A Geopolítica é o estudo do Estado como organismo geográfico, ou seja, como fenômeno localizado em certo espaço da Terra, portanto, do Estado como país, como território, como região ou, mais caracteristicamente, como domínio político." Diferenciando a geopolítica da geografia política, ele sustenta que "a geopolítica sempre tem em vista o Estado como unidade e contribui para o entendimento de sua natureza, enquanto que a geografia política estuda a Terra como sede de comunidades humanas, com respeito a seus atributos" (CHIAVENATO, 1981, p. 14-15).

Com o desenvolvimento dos meios de comunicação e transporte, o conceito de heartland seria relativizado pelo conceito de poder marítimo, formulado pelo almirante norte-americano Alfred Thayer Mahan (1840-1914), para quem a grandeza de uma nação dependia de seu comércio no além-mar, o comércio dependia do poder marítimo e o poder marítimo, das colônias (BANDEIRA, 2009, p. 51). A ascensão dos EUA ao status de potência mundial deveu-se muito à sua marinha mercante, e esta por sua vez exigia uma marinha de guerra para protegê-la. A expansão marítima norte-americana, ao tomar posse dos últimos remanescentes do império espanhol, como Porto Rico, Filipinas e Cuba, além da anexação do Havaí e do controle do istmo do Panamá, era norteada pela necessidade da instalação de centros logísticos para o abastecimento de seus navios, com vistas à projeção de seu poderio sobre a Ásia e a América Central.

Partindo dessas primeiras elaborações, podemos chegar às modernas definições de geopolítica. Para José W. Vesentini:

A palavra geopolítica não é uma simples contração de geografia política, como pensam alguns, mas sim algo que diz respeito às disputas de poder no espaço mundial e que, como a noção de PODER já o diz (poder implica em dominação, via Estado ou não, em relações de assimetria enfim, que podem ser culturais, sexuais, econômicas, repressivas elou militares, etc.), não é exclusivo da geografia. ${ }^{(1)}$

(1) VEZENTINI, José William. “O que é Geopolitica? e Geografia Política?” Geocrítica. Disponível em: <http://www.geocritica.com.br/geopolitica.htm>. Acessado em: 14.jul./2010. 
Feitas essas preliminares, podemos passar a um exame do pensamento geopolítico brasileiro e suas projeções sobre a realidade boliviana.

\section{GEOPOLÍTICA BRASILEIRA: SEUS PRIMÓRDIOS}

A Geopolítica no Brasil começa a tomar forma com o general Everardo Backeuser, que foi o primeiro a estimular seu estudo entre os militares. Backeuser, ao criar e ministrar o Curso de Geopolítica na Pontíficia Universidade Católica do Rio de Janeiro (1948). Mas é com o então capitão Mário Travassos que a geopolítica brasileira passa a ter uma elaboração original, a partir da publicação de seu livro Projeção continental do Brasil. Nesta obra, Travassos estabelece as bases que irão orientar todos os estudos geopolíticos brasileiros depois dele e estarão implícitas na política seguida pelo regime militar brasileiro a partir do golpe de 1964. Por sua importância, iremos nos deter um pouco nelas para compreender o seu papel na formulação das políticas de Estado no Brasil pós-64.

Para Travassos, havia dois antagonismos de massas continentais na América do Sul: do Atlântico contra o Pacífico e da Bacia do Amazonas contra a Bacia do Prata. Tais antagonismos consistiriam em forças centrífugas, criadas pela conjugação entre geografia e povoamento humano, aos quais teriam maior ou menor possibilidade de atuarem como meios de atração para o escoamento dos produtos produzidos no interior, tornando-se assim polos que regeriam toda a vida econômica das regiões sob sua influência e vias de entrada para os territórios do interior. O primeiro antagonismo abarca todo o continente. Chamado por Travassos de "o mar solitário", o Pacífico era um oceano com muito menos navegação, e com uma circulação de riquezas muito menor do que a efetuada no Atlântico, e os países sul-americanos por ele banhados sofriam a desvantagem de estarem muito longe dos centros internacionais europeus da época, ao contrário da vertente do Atlântico. Esse fato era ainda mais grave para os países "mediterrânicos", Bolívia, Paraguai e partes do Peru, que se localizavam no centro do continente e precisavam de uma fonte de escoamento para seu comércio. Daí a importância do segundo antagonismo fundamental na América do Sul.

O antagonismo do Amazonas contra o Prata seria o mais importante, pois é por intermédio do Prata que a vertente do Pacífico procuraria neutralizar suas desvantagens naturais para chegar ao mercado europeu. Cada uma das duas bacias tem sua origem no planalto boliviano, no próprio centro do continente e, a partir daí, se separam em direções diferentes, uma para o norte e outra para o sul, cada uma exercendo uma profunda influência sobre as regiões percorridas por ela até desaguarem no leste, em direção à Europa. "Ainda por essas duas formidáveis válvulas de segurança, em contacto direto com a civilização europeia, é que a vertente pacífica vai escapar a influências estranhas que seus vales longitudinais possam atrair e canalizar." (TRAVASSOS, 1935, p. 25.)

Travassos equaliza dessa forma tal antagonismo (1935, p. 113-114):

Em primeiro lugar, admitimos os dois imensos brasis que se procuram até as mais longínquas regiões da parte central do continente, representando ambos verdadeiros territórios de penetração, 
tendo como base o litoral atlântico. São eles o Brasil Amazônico e o Brasil Platino. (...) O Brasil Platino, apesar de requerer meios artificiais para unir-se ao oceano, dispõe de portos com suficiente capacidade de atração na costa e dos estímulos dos dois países mediterrâneos que reagem contra a força centrípeta do Prata: o sul do Mato Grosso, prolongando os territórios de São Paulo e Paraná, representa sua força de penetração.

Do ponto de vista do Brasil, tal antagonismo é agravado pela força convergente do Prata, que à época levava para Buenos Aires a influência sobre as bacias de seus formadores, os rios Uruguai, Paraná e Paraguai, todos os três mergulhando fundo no território brasileiro, além da rede de comunicações platinas que, conjugando via férrea e fluvial, alcançava o planalto boliviano e potencializava ao máximo a influência portenha sobre o centro do continente. Travassos não esconde sua admiração por tal empreendimento:

Com efeito, o quadro político argentino é, em nosso continente, exemplo notável do que de melhor se admita, no ponto de vista doutrinário, sobre o assunto. (...) Traduz, exatamente, ação coordenadora sobre os fatores geográficos e humanos condicionados pela nação argentina. Define com precisão as tendências, as necessidades e possibilidades do povo argentino, em si e em relação aos demais. (...) Se nas ligações Buenos Aires-Santigo e Buenos Aires-Assunción essa repercussão não ultrapassava os limites de suas naturais consequências, da ligação Buenos Aires-La Paz advêm reflexos capazes de repercussão até mesmo sobre a economia continental. (1935, p. 29.)

Nesse contexto geopolítico, se afirmará cada vez mais a importância do planalto boliviano como ponto convergente do antagonismo do Prata e do Amazonas, ao qual o Brasil precisaria conquistar para neutralizar a influência da Argentina sobre o continente. Para isso, bastaria aproveitar as vantagens naturais da posição brasileira. Aplicando a teoria das "fronteiras vivas" de Ratzel para o caso brasileiro, Travassos (1935, p. 114115) vai dizer que:

Consideradas também a extensão e a natureza das fronteiras terrestres com as nações hispano-americanas (vivas quanto ao Brasil da Bacia do Prata e mais ou menos mortas quanto ao Brasil amazônico), e o problema econômico da vertente atlântica sobre a do Pacífico, é evidente a importância decisiva dessas duas regiões nos vastos domínios não só da política interna, mas também da política continental. (...) Representam duas regiões convergentes em relação ao próprio centro geográfico do continente (altiplano boliviano), seja por meios artificiais (porto de Santos - rede Paulista-Noroeste), seja por vias de comunicação mais espontâneas, como são os rios da bacia amazônica.

Partindo dessas considerações, Travassos irá elaborar um conceito que lembra a teoria de Mackinder sobre a "ilha mundial", ao estabelecer então um "heartland" sul-americano: o triângulo compreendido entre Sucre, Cochabamba e Santa Cruz de la Sierra, onde estaria a "chave" para o equilíbrio do poder no subcontinente, por se conjugarem nessa área todos os principais antagonismos do subcontinente. Portanto, o Brasil teria um interesse capital nos eventos internos e externos bolivianos:

Com efeito, a situação da Bolívia é hoje das mais delicadas. Amarrada geologicamente à Cordilheira dos Andes, sofre diretamente os efeitos das discordâncias entre o Chile e o Peru. Traba- 
lhada pelas bacias amazônica e platina, oscila, instável, entre a Argentina e o Brasil. Como a verdadeira amputada da Guerra do Pacífico, e ante a indiferença brasileira, teve que sujeitar-se, sem direito de escolha, à influência argentina. (...) E de todo esse exame pode-se fixar de modo categórico o sentido político da Bolívia como o centro geográfico do continente e a causa eventual de conflito armado, cujo vulto poderá mesmo assumir o caráter de verdadeira conflagração. (1935, p. 63-64)

Para resolver o "problema" da hegemonia brasileira, "apenas se trata de deslocar o centro de atração da região de Cochabamba a Santa Cruz, inclusive porque a atração oferecida por Cochabamba é, por assim dizer, artificial, produto das facilidades de comunicações de que desfruta; em troca, Santa Cruz representa realmente o verdadeiro centro de gravidade da economia do altiplano". Este conceito do "triângulo boliviano" será de importância capital para o posterior desenvolvimento da geopolítica brasileira, e ecos seus podem ser encontrados na política exterior do regime militar.

Para enfatizar a importância que dava à questão das fronteiras bolivianas, Travassos vai dizer que:

As características brasileiras, tanto políticas como econômicas, resultantes de sua tradição histórica como de sua situação geográfica, determinam um verdadeiro imperativo para o Brasil, ao qual, naturalmente, sua política não poderá escapar. (...) Para expressar melhor essa afirmação, poderíamos dizer que, para a política brasileira, a Bolívia deste século é o Uruguai do século passado, agravando as questões pela colocação deste foco de controvérsias políticas sobre o próprio flanco do território brasileiro em sua parte mais sensível, dada a natureza viva de nossas fronteiras sudoeste e sul. Para completar este esboço, é preciso não se esquecer do território paraguaio, espécie de prolongamento de toda a angústia concentrada no território boliviano. (1935, p. 168)

O contexto geral em que Travassos desenvolve suas ideias está marcado pela Revolução de 30, cujo propósito de fortalecimento e modernização do Estado brasileiro encontra eco na obra do jovem capitão. Uma das preocupações do novo regime e dos círculos militares favorecidos com sua ascensão estava relacionada à segurança das fronteiras brasileiras, em especial com os estados platinos (Argentina e Paraguai), alvos de contestações e até de guerras no século anterior, e da vasta região amazônica, largamente desabitada e cujos marcos não estavam ainda bem delimitados e, portanto, poderiam ser alvo de futuras disputas.

Assim, será uma preocupação constante nas obras dos geopolíticos brasileiros o fortalecimento das fronteiras brasileiras e a ocupação do "vazio geopolítico" amazônico, eliminando o perigo da sua perda para algum país vizinho. A segunda obra mais importante de Mário Travassos será, de fato, um estudo a respeito da Introdução à Política de Comunicações Brasileiras, prefaciado por Gilberto Freyre. Segundo o general Meira Mattos, "as soluções sugeridas por Travassos visando à superação dos óbices oferecidos pela geografia sul-americana situam-se na realização de uma política de transportes que neutralize, a nosso favor, os desequilíbrios potenciais oferecidos pelos antagonismos fisiográficos existentes. Propõe que se implante ou se complete (quando for o caso) uma rede ferroviária carreadora para os portos brasileiros do Atlântico — Santos, Paranaguá, 
São Francisco, Porto Alegre e Rio Grande - as influências platinas sobre as regiões inferiores brasileiras das bacias dos rios Paraná, Paraguai e Uruguai. Propõe a chegada de nossos trilhos a Santa Cruz de La Sierra e daí, a Arica, articulando as grandes regiões platina (Atlântica) e andina (Pacífico). Sugere a construção de ramais da Estrada de Ferro Noroeste do Brasil para a República do Paraguai. Em termos de vertebração da massa continental sul-americana, sugere ampla conjugação das redes ferroviária, hidroviária e aérea, além de propor a criação de um sistema aéreo interligando todas as capitais dos países de nosso subcontinente austral, superando assim, temporariamente, as dificuldades de tráfego terrestre oferecidas pelos obstáculos geográficos"(MEIRA MATOS, 1975, p. 52).

Uma importante preocupação dos militares brasileiros na época era o temor ao expansionismo da Argentina e a preparação para um possível confronto com o país vizinho. Isso porque a Argentina, no começo dos anos 1930, estava em melhores condições que o Brasil para estender sua influência até o Oriente boliviano por meio da bacia do Prata e da construção de uma malha viária que fizesse a economia da região gravitar em torno do porto de Buenos Aires. Segundo Brum Vieira (2006, p. 54), para os geopolíticos brasileiros, em especial os de formação militar, a "hegemonia brasileira sobre a América do Sul, portanto, levaria à necessidade de neutralizar a suposta hegemonia da Argentina sobre a Bolívia e, acessoriamente, também sobre o Paraguai".

Mário Travassos (1935, p. 63), em seu livro, já demonstra sua preocupação com a influência argentina sobre a Bolívia:

(...) a situação da Bolivia é hoje das mais delicadas (...). Trabalhada pelas bacias amazônica e platina, oscila, instável, entre a Argentina e o Brasil. Como a verdadeira amputada da Guerra do Pacífico e ante a indiferença brasileira, teve de sujeitar-se, sem direito de escolha, à influência argentina.

Para mudar essa situação, ele propõe a construção de uma malha ferroviária brasileira, ligando Santa Cruz a Corumbá, para, desse modo, "criar uma via de acesso ao Atlântico para a Bolívia pelo território brasileiro até Santos, desviando o fluxo comercial daquele país do eixo vertical platino" (1935, p. 86).

\section{Geopolítica brasileira na Guerra do Chaco}

A Guerra do Chaco (1932-1935), entre Bolívia e Paraguai, foi acompanhada ativamente pelos círculos militares brasileiros e argentinos, que a viam não como um conflito puramente bélico entre terceiras nações, mas como um evento que envolvia questões geopolíticas e de projeção sobre o centro do continente. Para vários militares brasileiros, uma guerra contra a Argentina era uma hipótese muito concreta em meados da década de 1930, caso o avanço paraguaio sobre a Bolívia se concretizasse (SILVEIRA, 2009, p. 662).

O Paraguai recebia apoio informal da Argentina, apesar desta ter de clarado sua neutralidade no conflito, e sua vitória sobre a Bolívia e a conquista do Chaco eram 
encarados pelos militares brasileiros como uma vitória das ambições platinas sobre os desejos de projeção brasileiros. Silveira (2009) faz um interessante estudo sobre "A visão militar brasileira da Guerra do Chaco". Nele, analisa um relatório do General de Divisão Waldomiro Castilho de Lima, membro do Conselho Superior de Guerra, que estuda a guerra do Chaco em sua relação com o interesse nacional brasileiro. Para Silveira, o documento é importante porque mostra que "a posição central da Argentina nas projeções estratégicas brasileiras, atualizada para a década de 1930 por Mário Travassos, encontra, concretamente, notável instrumentalização no meio militar" (2009, p. 659).

O general faz uma inquietante constatação sobre o equilíbrio de poder e a supremacia militar na América do Sul: "O Brasil perdeu a supremacia militar sul-americana que possuía até a época da Guerra do Paraguai" (p. 659), diz logo em sua primeira página. Depois, discorre sobre a situação militar argentina, que chama de "potência de primeira grandeza no nosso continente", uma constatação que era consenso e preocupava os nossos militares: a Argentina desfrutava de superioridade em praticamente todos os setores estratégicos, como transportes, aviação, artilharia, infantaria e marinha.

No plano estratégico mais amplo, "considerava-se praticamente inevitável a união dos Estados hispano-platinos contra o Brasil", liderados pela Argentina. De fato, "parecia bastante presente a hipótese de que o confronto boliviano-paraguaio conduzisse Brasil e Argentina à guerra". Havia também a questão dos interesses norte-americanos da região, em especial os da petrolífera Standard Oil, que explorava petróleo no território dos prováveis aliados do Brasil: Chile, Peru e Bolívia. A perspectiva de se encontrar ricas jazidas no território em disputa (que ao final não se materializou) foi um dos motivos para a eclosão das hostilidades. O presidente da Bolívia, Daniel Salamanca, imaginava que a região dispunha de reservas de petróleo suficientes para abastecer o mundo e tirar o país do subdesenvolvimento e, para isso, precisava apenas de acesso ao Oceano Atlântico, pelo rio Paraguai e pelo estuário do Prata (BANDEIRA, 1998, p. 175). O presidente do Paraguai, Eusébio Ayala, possuía uma opinião semelhante, e sua esperança era conquistar o território, para assim ressarcir o Paraguai dos custos de guerra.

Para o general brasileiro Castilho de Lima, em sua análise dos interesses americanos na região, "o pensamento estratégico brasileiro vê como coincidentes os interesses do Brasil e dos EUA no subcontinente" (SILVEIRA, 2009, p. 665), numa tradição que começa com Rio Branco e iria se perpetuar nas elaborações geopolíticas das décadas de 1960 e $1970^{(2)}$.

A principal preocupação da diplomacia brasileira, a seu ver, deveria ser impedir a expansão do poder argentino sobre a região central da América do Sul, por meio da projeção de sua malha ferroviária sobre a Bolívia e Paraguai. Nesse contexto, a inteligência militar brasileira via com muita preocupação o avanço paraguaio sobre todo o território

(2) De fato, até Travassos, em "Projeção" (p. 89), alude ao poderio econômico norte-americano, com uma resignação que prenunciará o tom do futuro relacionamento dos militares brasileiros com o governo americano: "A influência mundial dos Estados Unidos é hoje realidade que se não discute. Cresce com a importância cada vez mais acentuada de suas relações financeiras e econômicas com os demais países. É servidão contra a qual inutilmente se debatem os que contra ela se revoltam." (grifos nossos) 
em disputa e sobre a fronteira brasileira. Temia-se que as tropas paraguaias continuassem seu avanço até o coração do continente, chegando a Santa Cruz e cortando as ligações entre o Altiplano e o Oriente. Esse movimento, se concretizado, traria sérias consequências para a posição brasileira no subcontinente (SILVEIRA, 2009, p. 660). Dada a subordinação paraguaia à Argentina, o controle militar — e, provavelmente, jurídico - do Paraguai traria todo o Oriente boliviano e, portanto, o coração continental, para a órbita da influência do Estado platino, abrindo o vale do Amazonas à sua infiltração (BANDEIRA, 1998, p. 175).

A isso o Brasil se oporia, indo até mesmo à guerra, pois para ele constituiria casus belli o desmembramento de qualquer parte da Bolívia, cujo estatuto territorial considerava "definitivo e não passível de quaisquer modificações" na parte em que estava jurídica e formalmente definido, admitido ou reconhecido, nas palavras do embaixador Mario de Pimentel Brandão a Alberto Ostria Gutierrez, Enviado Extraordinário e Ministro Plenipotenciário da Bolívia (BANDEIRA, 1998, p. 187).

O que o general Castilho de Lima propunha ao Conselho Superior de Guerra para conter a expansão da influência argentina (e aqui ele mostra que assimilou bem as teses de Travassos) era elaborar um projeto próprio de ferrovias que atraísse para a órbita brasileira a Bolívia e, adicionalmente, o Paraguai: A guerra, "debilitando a economia paraguaia, transformaria o controle argentino desta economia em uma verdadeira asfixia". Assim, se abria a possibilidade para o Brasil oferecer ao Paraguai uma saída alternativa para o Atlântico por meio de ligação ferroviária de Assunción até o eixo portuário Rio Grande-Santos (SILVEIRA, 2009, p. 664). O general é explícito no sentido estratégico dessa ligação:

(...) essas comunicações, livrando o Paraguai da dependência e despotismo econômico argentino, afastariam de nós o perigo da união íntima desse país com a Argentina, aproximando-o mais do Brasil e oferecendo-nos certa garantia de benevolente neutralidade dessa República em caso de uma guerra Brasil-Argentina.

Por outro lado, também não se devia esquecer da Bolívia. Dizendo que "não nos interessa mais a política usada pelo império, de assegurar à Bolívia uma saída pelo rio Paraguai", ele recomenda que o Brasil auxiliasse imediatamente a Bolívia na construção da ferrovia Santa Cruz-Porto Suárez, e propondo a construção de outra, ligando Santa Cruz a Corumbá. Para o Brasil, a única forma de evitar a secessão do território do Oriente seria romper a situação de mediterraneidade boliviana oferecendo-lhe uma saída para o Atlântico alternativa ao rio da Prata, atraindo-o para a órbita brasileira. Segundo o general, essa era uma das questões mais urgentes, pois a Argentina já estava à frente do Brasil na realização de seus planos ferroviários, o que colocava o país diante de duas variáveis altamente negativas: “(...) conseguida para a Bolívia uma saída para o rio Paraguai continuarão os produtos desse país a se escoar para o Prata. Negada aquela saída, o seu plano ferroviário [da Argentina] terá mais rápida execução.” (SILVEIRA, 2009, p. 66.)

A Conferência de Paz, realizada em Buenos Aires, culminou no Tratado de Paz, Amizade e Limites, assinado por Bolívia e Paraguai em 21 de julho de 1938. Para Moniz Bandeira, "nenhum dos dois países realizou, efetivamente, seus objetivos. Nem o Paraguai conseguiu capturar a zona de petróleo, (...) nem a Bolívia pôde expandir seu 
território até as margens do rio Paraguai, (...). Assim, os grandes vencedores (...) foram o Brasil e a Argentina. Ao firmarem os tratados de vinculação ferroviária, Santa Cruz de la Sierra-Corumbá e Santa Cruz de la Sierra-Yacuiba, esses dois países receberam enormes concessões para explorar um petróleo que, conforme se comprovou, jamais em grande quantidade comercial apareceu" (BANDEIRA, 1998, p. 189).

A guerra do Chaco também foi importante porque nela importantes figuras militares ligadas às esferas de tomada de decisão do governo passaram a elaborar uma política de projeção brasileira na América do Sul com claros componentes geopolíticos. Alguns traços que seriam dominantes nos geopolíticos brasileiros posteriores já estavam presentes no relatório do General Castilho de Lima: a necessidade de neutralizar a Argentina como nosso principal rival no subcontinente; a convergência de interesses entre Brasil e Estados Unidos; e a necessidade de trazer para a órbita brasileira a Bolívia e o Paraguai.

\section{Geopolítica brasileira nos anos 1950-60: O PAPel Da ESG}

A partir do final dos anos 1950 e início dos anos 1960, a geopolítica ocuparia um papel de destaque na formação dos quadros militares dirigentes de nossas forças armadas. Criada em 1949, modelada no National War College dos Estados Unidos, a Escola Superior de Guerra (ESG) teria uma atuação destacada na difusão do pensamento geopolítico e da Doutrina de Segurança Nacional, calcada em elementos claramente geopolíticos.

Nessa época, o contexto mundial era marcado pela ideologia da Guerra Fria e do tensionamento das relações internacionais em decorrência da bipolaridade entre as duas grandes superpotências. Preocupados em garantir sua influência sobre uma região vital para sua estratégia geopolítica, os Estados Unidos, além das intervenções armadas que realizavam desde os anos 1930 na América Central, idealizaram para a América do Sul uma estratégia que tinha no Brasil o principal parceiro no combate à "subversão" (BANDEIRA, 2008).

A elaboração dessa estratégia foi facilitada pelo fato de que, entre as classes dirigentes brasileiras, há muito havia sido consolidada a visão de que os interesses norte-americanos na América do Sul eram convergentes com os do Brasil. Além de relações comerciais e políticas, estabeleceu-se um intenso intercâmbio entre as Forças Armadas dos dois países, com militares brasileiros comparecendo a cursos nos Estados Unidos, uma prática que ocorria desde o envolvimento do Brasil na Segunda Guerra Mundial. Esses intercâmbios sintonizaram os militares brasileiros com os principais objetivos estratégicos norte-americanos para o hemisfério.

A ESG, como órgão diretamente subordinado ao Estado-Maior das Forças Armadas, foi central na difusão ideológica, entre elites civis e militares, dos novos conceitos de Segurança Nacional que eram elaborados em conjunto com as Forças Armadas americanas. Ela funcionou, assim, como um verdadeiro aparelho privado de hegemonia, no sentido gramsciano da palavra ${ }^{(3)}$.

(3) Aparelhos privados de hegemonia, segundo Gramsci, são instâncias associativas, de cunho voluntário, formalmente distintas da organização das empresas e das instituições estatais, e apresentam-se sob inúmeros formatos: clubes, partidos, jornais, revistas, igrejas etc. Embora muitas vezes se apresentem como descolados de qualquer embate 
Após a Guerra da Coreia (1951-1953), há uma importante mudança nos conceitos de Segurança Nacional, a partir de sua internalização. Abandonando a perspectiva de um confronto direto entre o bloco comunista e o Ocidente liderado pelos Estados Unidos, o comunismo era visto agora como um inimigo interno, que se aproveitaria das contradições internas resultantes do estágio de desenvolvimento do Brasil para lançar sua influência desestabilizadora. Portanto, a Segurança Nacional não mais se limitava aos aspectos militares, mas passava a englobar em sua esfera de interesse assuntos de ordem econômica, social, diplomática e política. Era a gestação de um projeto nacional, no qual o planejamento da segurança nacional deveria subordinar as demais atividades da nação $0^{(4)}$.

Nesse sentido, a ESG se tornaria o principal centro de crítica ao Estado brasileiro, a partir de sua avaliação negativa a respeito do preparo das elites políticas para resolver os problemas sociais e da adequação das instituições políticas e governamentais para o encaminhamento de soluções para esses problemas. Sua missão, a partir dessa avaliação, será a preparação de uma elite, técnica e militarmente preparada, para o exame de questões e problemas referentes à Segurança Nacional. Sua estratégia não passaria pela mobilização de amplos setores da opinião pública, mas pelo posicionamento estratégico de quadros oriundos de seus cursos em importantes postos no aparelho de Estado e no Exército. O General Antonio Jorge Correia, ex-chefe do Estado Maior do Exército, afirma que a inspiração para a criação da ESG foi:

A consciência de que era mister criar uma elite preparada para a missão de interpretar as legítimas aspirações e autênticos interesses nacionais, de formular, através de método científico, a política e estratégia nacionais [além da] consciência de que o Brasil já possuía os requisitos para chegar à categoria de Grande Potência (e que) o desenvolvimento vinha sendo retardado pela incapacidade de planejamento e execução. (OLIVEIRA, 1976, p. 24.)

O principal expoente do pensamento da ESG foi o general Golbery do Couto e Silva (1911-1987). Adjunto do Departamento de Estudos da Escola Superior de Guerra, ele

político-econômico, sua origem está ligada à complexificação da vida urbana capitalista e da necessidade, por parte de setores da classe dominante, de encontrar novas formas de obtenção do consentimento e obediência, por parte da classe subalterna, para a sua ideologia e organização social. Apesar de heterogêneas em suas formas organizativas e composição, têm uma importante função na criação de coesão entre os membros do tecido social e na adaptação desses membros às novas formas de sociabilidade e organização industrial trazidas pelo desenvolvimento do capitalismo. O campo de atuação desses aparelhos, então, seria principalmente no plano da "cultura", mas com consideráveis repercussões nos campos econômico e político. Uma forma importante de cumprirem sua tarefa é se apresentarem como portadores de uma "neutralidade informativa", no caso dos jornais, ou de "interesses nacionais", escamoteando assim seu conteúdo de classe. Ver, a esse respeito, GRAMSCI (2001) e FONTES (2010). Embora formalmente ligada a uma instituição estatal (as Forças Armadas), a ESG, em nossa hipótese, cumpriu o mesmo papel de difusão de uma produção intelectual coletiva que visava defender os interesses da classe dominante brasileira (sua hegemonia), além de fornecer um espaço de sociabilidade que uniu militares a diversos elementos da burguesia brasileira, criando vínculos pessoais e políticos entre militares e civis que participariam do golpe contra João Goulart e passariam a ter importante influência nos governos militares, numa rede associativa que, por exemplo, teria continuidade na atuação da Associação de Diplomados da Escola Superior de Guerra (ADESG), criada em 1951 para "manter o espírito das ideias" dessa instituição, e que se organiza em cursos regulares promovidos por suas delegacias estaduais.

(4) O mais lúcido expoente desse pensamento foi o general Golbery do Couto e Silva, nas teses defendidas em seu livro Geopolítica do Brasil (1981). 
ali começou a desenvolver suas teses geopolíticas; entre elas, a da necessidade de uma associação do Estado à iniciativa privada mediante o apoio tecnocrático, de forma a fortalecer a segurança nacional.

Golbery foi uma figura central na articulação do golpe que viria a derrubar o presidente João Goulart e levar ao poder os militares identificados com os pressupostos da Doutrina de Segurança Nacional. Como diretor do Instituto de Pesquisas e Estudos Sociais (IPES), conseguiu montar uma extensa rede de informações com a ajuda de financiamento de empresários ligados aos setores golpistas. Essas informações, logo depois do golpe, foram transferidas para o recém-formado Serviço Nacional de Informações (SNI), criado em 1964, e também dirigido pelo general Golbery.

Em 1966, ele escreveu sua obra mais importante, o livro Geopolitica do Brasil, que teria grande destaque na comunidade de informações nacional e internacional, e apresentaria de forma mais completa suas ideias geopolíticas. Antes de tudo, a sua concepção de geopolítica possuia um caráter totalizante, que pretendia englobar e subordinar todos os ramos do conhecimento às necessidades de "segurança":

A Geopolítica é sobretudo uma arte — arte subordinada à Politica e, em particular, à Estratégia ou Política de Segurança Nacional, tratando de orientá-la à luz da geografia dos espaços politicamente organizados pelo homem. Seus fundamentos radicam, pois, em uma Geografia Política, mas seus propósitos projetam-se dinamicamente até o futuro. (...) De qualquer forma, por mais ampla que seja sua perspectiva, abarcando toda a realidade politica, econômica e inclusive cultural em que se situa o Estado, superando, como é normal e talvez inevitável - quem poderá considerá-lo pernicioso? - a história, a psicologia, a sociologia e ainda a estratégia especificamente militar, a Geopolitica adota sempre o ponto de vista único e privativo — o do espaço físico —, pois este deve ser elemento não exclusivo mais sim dominante da paisagem que ela trata de interpretar, com a finalidade prática de discernir ai a margem de possibilidades que serão aproveitadas na construção da maior grandeza, do crescente progresso e da segurança interna e externa do Estado, beneficiando-se das vantagens positivas que ofereça a terra e neutralizando, na medida do possivel, os aspectos negativos que ela apresenta em sua imparcialidade incomovivel. (COUTO E SILVA, 1981, p. 34-35.)

A geopolítica, assim, oferecia-se como um atraente instrumento ideológico de luta pelo poder, que uniria o grupo de tecnocratas que subiria ao poder com o golpe de 1964 e transformaria seus pressupostos em política de Estado, realizando na prática a "projeção continental" que o general Mário Travassos sugeria já na década de 1930. A sua força residia justamente em que apresentava uma perspectiva sedutora de realização de um "destino manifesto" latente na própria conformação geográfica e histórica do Brasil, ao mesmo tempo em que dava-lhes ferramentas capazes de racionalizar e atuar sobre uma realidade complexa. Era assim que Golbery via a posição hemisférica do Brasil:

Na verdade, o Brasil é bem um "império"(5), vasto império compacto, de ampla frente marítima e dilatada fronteira continental equidependentes quase em torno do eixo de simetria

(5) O uso do termo "império" para descrever a formação histórica e social do Brasil não é acidental no pensamento de Golbery. Mais à frente, na mesma obra (p. 110), ele vai falar de "um indiscutível espírito imperialista [brasileiro], 
norte-sul que vai do Cabo Orange à barra do Chuí. (...) Ocupa, sem dúvida, aquela frente marítima, uma posição um tanto marginal no caprichoso contorno do oceano mundial em que o Atlântico Sul nada mais é que um golfão ainda excêntrico. (...) Estende-se aquela fronteira terrestre, em grande parte, através do deserto em que a Hiléia domina como vastíssimo cinturão protetor. (...). É, de fato, a própria insularidade, em proporções continentais. (COUTO E SILVA, 1981, p. 108)

Dentro deste aspecto, o "heartland" brasileiro, a área do interior do Brasil para onde se deveria transferir a sede do governo a fim de estimular o povoamento da região (uma ideia antiga entre políticos e intelectuais brasileiros, concretizada com a construção de Brasília), "traz inscrito em si mesmo um destino imperial manifesto". O general entendia por isso o alargamento da "influência dinamizadora de nosso núcleo irradiador de progresso", uma nova "marcha para o Oeste", que ocupasse os vazios geográficos brasileiros, dando assim um "impulso decisivo à política de continentalidade".

Outro eixo central de sua concepção era de que a segurança nacional do Brasil exigia o integral posicionamento do Brasil com o "Ocidente" (ou seja, os Estados Unidos), em confronto com o bloco soviético. No mundo polarizado de então, a realização do "destino imperial manifesto" brasileiro estaria em estreita conjunção com a sua aliança com os Estados Unidos, para assegurar a manutenção do status quo no Hemisfério Sul:

Quando entre nossos vizinhos hispano-americanos recrudesce indisfarçável uma oposição aos Estados Unidos que se mascara de Terceira Posição $o^{(6)}$ ou que outro rótulo tenha (...) o Brasil parece estar em condições superiores, por sua economia não-competitiva, por sua larga e comprovada tradição de amizade e, sobretudo, pelos triunfos de que dispõe para uma barganha leal —o manganês, as areias monazíticas, as posições estratégicas do Nordeste e da embocadura amazônica com seu tampão de Marajó - de negociar uma aliança bilateral mais expressiva, que não só nos assegure os recursos necessários para concorrermos substancialmente na segurança do Atlântico Sul e defendermos, se for o caso, aquelas áreas brasileiras tão expostas a ameaças extracontinentais contra um ataque envolvendo ao território norte-americano via Dacar-Brasil-Antilhas. (...). (COUTO E SILVA, 1981, p. 248.)

Para terminar nossa exposição sobre os principais geopolíticos brasileiros, devemos citar o general Meira Mattos (1913-2007), adido militar na Bolívia em 1965 e vice-chefe do gabinete militar do governo Castello Branco. Sua importância está mais em ser um divulgador das ideias anteriores do que por alguma contribuição original. No entanto, ele teve enorme influência sobre grande número de quadros civis e militares do regime militar por seu ufanismo e otimismo, que pareciam dar um embasamento científico ao clima de euforia vivido nos anos 1970.

alerta e vigoroso, muitas vezes até mesmo incontido e extravagante, que bem traduz uma herança duradoura daqueles insuperáveis desbravadores de todo um continente intacto em quem Saint-Hilaire viu, outrora, uma formidável 'raça de gigantes"'.

(6) Pela referência à Terceira Posição, Golbery tinha em mente a Argentina, que continuava a ser a maior rival brasileira na América do Sul, e cujo regime populista do General Perón tentava se manter afastado das pressões norte-americanas apelando para uma "terceira posição" entre o bloco ocidental liderado pelos EUA e o mundo socialista liderado pela União Soviética. 
Quanto à concepção tavariana sobre o triângulo boliviano, Meira Mattos é um fiel partidário dela. Em um artigo publicado na Folha de São Paulo (16.06.2006), após as nacionalizações efetuadas pelo governo Evo Morales, ele analisa a instabilidade boliviana como sendo um produto da sua posição geográfica, dando a entender sua inviabilidade como país. Apesar da extensão, vale a pena citá-lo quase na íntegra:

A Bolívia nasceu historicamente fadada à instabilidade política. Em 1824, após vencer os espanhóis em Ayacucho, conquistando o Peru, Bolivar enviou o general Sucre ao Alto Peru (hoje Bolívia), a fim de expulsar o restante das forças espanholas que lá haviam se refugiado. (...)

Documentos históricos registram que ao receber a comunicação de Sucre sobre a criação do novo Estado, o libertador em carta censurou o seu general, por ter concordado com a fundação de um Estado independente em região geopoliticamente dependente e que seria um foco permanente de instabilidade. (...) A previsão de Bolívar realizou-se. Desde sua independência, em 1826, a Bolívia vive um ambiente de constante instabilidade politica e social. Nasceu com cerca de 2 milhões de $\mathrm{km}^{2}$. Durante os seus primeiros cem anos de existência, perdeu para seus vizinhos - Argentina, Chile, Paraguai, Peru e Brasil (Acre) — cerca de metade de seu território inicial. (...) A profética antevisão de Simón Bolivar, fundada na sua intuição geopolítica, provinha da avaliação de uma realidade geográfica potencial quando se trata de constituir uma unidade política coesa.

O território do Alto Peru é formado pelas partes interiores, secundárias, de duas grandes bacias hidrográficas, Prata e Amazônica, e de um trecho intermediário do sistema andino. (...) Todas essas três partes são dependentes geográficas e naturalmente submetidas à atração política do centrefugismo do eixo dos sistemas: a bacia do Prata corre para a sua foz no Atlântico Sul. A bacia Amazônica puxa para sua foz do Atlântico Norte e a porção andina do país, a menos ecumenizada, não pode subtrair-se da vinculação com os segmentos norte e sul do sistema andino. (...) A esses fatores de uma geografia dispersiva veio agravar a perda de seu litoral no Pacífico na guerra contra o Chile (1879-1884), que o tornou um país mediterrâneo. (...)

Por tudo o que foi exposto, podemos ver o determinismo geográfico como componente ideológico importante na construção da visão geopolítica brasileira. Desde Mário Travassos, a Bolívia é considerada um país "historicamente"(7) fadado à instabilidade, sem unidade territorial, presa de influências geográficas conflitantes e, portanto, passível de ser "capturado" para a órbita de um vizinho mais forte. A penetração brasileira na Bolívia, assim, estava justificada pela geografia e era vista como uma necessidade e prolongamento natural da integração e ocupação do nosso território, em especial na região amazônica, se quiséssemos neutralizar a ameaça representada pela Argentina.

(7) Em verdade, a visão geopolítica brasileira, no que concerne aos países menores, como Bolívia e Paraguai, nada tem de histórica, é uma construção ideológica que usa o determinismo geográfico como uma justificativa pos facto de um processo que possui causas que vão além da geografia. É interessante observar que o próprio Travassos não partilha em muitos casos desse determinismo de seus sucessores. Uma leitura crítica de sua obra Projeção Continental mostra que, como observador atento dos fatores naturais e humanos, ele procurava chamar atenção para o fato de que, apesar de suas vantagens naturais proporcionadas pela geografia, o Brasil poderia perder a disputa pela supremacia sul-americana porque, ao contrário da Argentina, não possuía uma política de transportes coerente e sistemática que integrasse o seu território e o ligasse aos países vizinhos. Mais do que um apologista de uma suposta "grandeza natural" do Brasil, ele buscava despertar nos estadistas e militares da época a necessidade de uma política de Estado que levasse em conta os aspectos geográficos para a planificação do desenvolvimento do território. 
Uma vez tendo acesso aos mecanismos de tomada de decisão do Estado, os tecnocratas adeptos das ideias geopolíticas irão orientar as políticas estatais embasados nesta concepção, procurando "neutralizar" os pontos fracos do território e trazer para a órbita da influência brasileira o eixo econômico da Bolívia e Paraguai, transformando esses dois países em virtuais "satélites" brasileiros, enfraquecendo assim a Argentina como a principal rival ao projeto de hegemonia brasileira.

Na década de 1970, um importante marco nas relações entre Brasil e Bolívia se deu com o Acordo de Cooperação e Complementação Industrial, assinado em janeiro de 1974 entre os presidentes Banzer e Geisel na cidade de Cochabamba. Nele, o gás aparecia pela primeira vez como uma pauta importante: a Bolívia se comprometia a fornecer ao Brasil 240 milhões de pés cúbicos diários (MMPCD) de gás natural, por um período de vinte anos. Além disso, tal acordo previa uma série de disposições a respeito de financiamentos, garantias e assistência técnica extremamente desvantajosas para a Bolívia, transformando-a em uma reserva de mercados para produtos brasileiros, além de comprometer a totalidade das reservas bolivianas de gás natural para o fornecimento à indústria paulista. Outro ponto importante foi o projeto de construção de estradas, que visavam conectar o centro-sul do Brasil a um porto no Pacífico, reduzindo assim o tempo de transporte das mercadorias brasileiras para o mercado asiático em expansão.

Não foi possível implementar tal acordo na época, em parte por causa das dificuldades econômicas decorrentes da crise da dívida, em parte por causa da violenta reação que suscitou na sociedade boliviana ${ }^{(8)}$. Mas o que importa é assinalar que este acordo pode ser visto como o marco inicial que irá balizar todos os acordos posteriores de cooperação entre os dois países. Mesmo após o fim das ditaduras militares, todos os acordos realizados por Brasil e Bolívia serão norteados por dois pontos fundamentais: 1) o Brasil tentaria garantir para si grandes reservas de gás boliviano para sua indústria; e 2) tentaria envolver a Bolívia em um esquema de integração econômica cujas diretrizes, emanadas da concepção de regionalismo aberto, destinam a ela o papel de país de trânsito de mercadorias destinadas à exportação e fornecedor de matérias-primas baratas (CARPIO, 2010). A controvérsia acerca das novas nacionalizações do atual governo Evo Morales, ou das construtoras brasileiras que operam no país, são apenas alguns dos episódios mais recente de uma história cujos primórdios remontam à década de 1930.

\section{CONClusÃo}

Este artigo procurou entender os pressupostos ideológicos que orientaram as ações políticas e diplomáticas do Estado brasileiro em relação à Bolívia, país que muito cedo adquiriu grande importância para os nossos estrategistas militares e civis, graças a sua posição no centro do continente e sua riqueza em recursos minerais. Por isso, nos demoramos em analisar o desenvolvimento do pensamento geopolítico brasileiro,

(8) Uma extensa e detalhada análise desses acordos está em QUIROGA SANTA CRUZ, Marcelo. Oleocracia o Patria. La Paz: Plural Editores, 1977. 
com as contribuições de Mário Travassos e seus seguidores, que partiam de uma perspectiva de fortalecimento do Estado e neutralização de possíveis ameaças à integridade territorial brasileira. Por muito tempo, a geopolítica brasileira se orientou em função da rivalidade com a Argentina. Após essa ter abandonado qualquer perspectiva de alcançar uma hegemonia no Cone Sul, ela passa a aceitar acordos de integração regional capitaneados pelo Brasil (como o MERCOSUL). E, com isso, a histórica oscilação dos países mediterrâneos (Paraguai e Bolívia) entre os dois principais países do subcontinente não será mais possível, levando-os também a buscarem a integração comercial sob a égide brasileira.

Com isso, empresas brasileiras nos setores de construção, agropecuária e mineração encontram um ambiente favorável para a expansão de suas atividades no resto da América do Sul, num momento de fortalecimento do papel internacional do Brasil. O movimento geopolítico visando a hegemonia sobre a América do Sul, imaginado nos anos 1930 por Mário Travassos, encontra na integração regional (com seus ambiciosos projetos de integração física, como estradas, hidrelétricas e hidrovias) uma nova atualização.

\section{REFERÊNCIAS BibLIOGRÁFICAS}

BANDEIRA, Luiz Alberto Moniz. Formação do Império Americano. Rio de Janeiro: Civilização Brasileira, 2009.

BANDEIRA, Luiz Alberto Moniz. A importância geopolítica da América do Sul na estratégia dos Estados Unidos. Revista Espaço Acadêmico: São Paulo, n. 89, outubro de 2008. Disponível em: < http://www. espacoacademico.com.br/089/89bandeira.pdf>.

BANDEIRA, Luiz Alberto Moniz. A Guerra do Chaco. Revista Brasileira de Política Internacional. Brasília, p. 162-197, v. 41, nº 1, 1998. Disponível em: <http://www.scielo.br/scielo.php?pid=S003473291998000100008\&script=sci_arttext $>$.

BERNAL-MEZA, Raul. Argentina y Brasil en la politica internacional: regionalismo y MERCOSUR (estratégias, cooperação y factores de tensión). Disponível em: <http://www.academicoo.com/tese-dissertacao/argentina-y-brasil-en-la-politica-internacional-regionalismo-y-mercosur-estrategias-cooperacion-y-factores-de-tension>.

CARPIO, Silvia Molina. Corredor Norte: Nación integrada o país de trânsito. La Paz: FOBOMADE, 2010. CHIAVENATO, Júlio José. Geopolítica, arma do fascismo. São Paulo: Ed. Global, 1981.

COUTO E SILVA, Golbery. Conjuntura Política Nacional, o Poder Executivo E Geopolítica do Brasil. Rio de Janeiro: José Olympio Editora, 1981.

DAVILA, Anapaula Iacovino. Itaipu e Gasoduto Brasil-Bolívia: Estratégias geopolíticas na América Latina? Disponível em: <http://www.americalatina.org.br/internas.php? noticias=\&interna=22140>. FONTES, Virgínia. O Brasil e o capital-imperialismo. Rio de Janeiro: Ed. da UFRJ, 2010.

LIMA, Maria Regina Soares de. A Economia Política da Política Externa Brasileira: Uma proposta de análise. Contexto Internacional, Rio de Janeiro: p. 7-28, nº 12, jul./dez. 1990.

MEIRA MATTOS, Carlos de. A geopolítica e as projeções do poder. Rio de Janeiro: Biblioteca do Exército, 1977.

MEIRA MATTOS, Carlos de. Brasil, geopolítica e destino. Rio de Janeiro: Biblioteca do Exército, 1975. 
OLIVEIRA, Eliezer Rizzo de. As Forças Armadas: Política e ideologia no Brasil (1964-1969). Petrópolis: Ed. Vozes, 1976.

QUIROGA SANTA CRUZ, Marcelo. Oleocracia o Patria. La Paz: Plural Editores, 1977.

SILVEIRA, Helder Gordim. A Visão Militar Brasileira da Guerra do Chaco. Revista Antíteses. Londrina: p. 649-667, v. 2, no 4, jul./dez. 2009.

SOUZA, Angelita Matos. Oexpansionismo nos governos Lula e o BNDES. Disponível em: <http://www. red.unb.br/index.php/MED/article/viewArticle/581>.

TRAVASSOS, Mário. Projeção continental do Brasil. São Paulo: Companhia Editora Nacional, 1935. 